\title{
Controlling Water Hyacinth in Lake Tana Using Biological Method at Green House and Pond Level
}

\author{
Adugnaw Admas*, Samuael Sahle, Erehmet Belete, Aklilu Agidie and Mehari Alebachew
}

Ethiopian Environment and Forest Research Institute P.O.Box:24536 code 1000 Addis Ababa, Ethiopia

Corresponding author: Adugnaw Admas, Ethiopian Environment and Forest Research Institute P.O.Box:24536 code 1000 Addis Ababa, Ethiopia, Tel: +251918 561763; E-mail: adu.biot@gmail.com

Received Date: September 13, 2017; Accepted Date: October 03, 2017; Published Date: October 13, 2017

Copyright: (c) 2017 Admas A, et al. This is an open-access article distributed under the terms of the Creative Commons Attribution License, which permits unrestricted use, distribution, and reproduction in any medium, provided the original author and source are credited.

Citation: Admas A, Sahle S, Belete E, Agidie A, Alebachew M, et al. (2017) Controlling Water Hyacinth in Lake Tana Using Biological Method at Green House and Pond Level. Eur Exp Biol. Vol. 7 No. 5:30.

\section{Abstract}

Water hyacinth (Eichhornia crassipes) is one of the most dangerous aquatic weeds for Lake Tana. To minimize invasion; biological, chemical and physical control methods can be used. Biological control based on the use of natural enemies of the weed to discourage its development was the best option. Plant pathogenic associated with naturally infected Faba bean by fungus was conducted at different sites with the objective of study the pathogen city indigenous fungi on water hyacinth to manage its spread on Lake Tana. Infected fungus plant samples were collected from three weredas (Amba Gyorgese, Dabat and Debarke) around Gondar at 20 Peasant association (PAs), The collection were done for infected Faba bean leaves and roots and isolated using Potato Dextrose Agar medium. Highest disease incidence per plant was recorded in water hyacinth plants using Using Modified Naseema et al. (2001) disease severity rating scale by inoculated with Rhizoctonia solani spp. Aspergillus flavus, Tricothcium roseum, Fusarium spp and Aspergillus niger show high moderate disease severity and tissue death at green house and pond level. Those fungus were released on September 2016 to prepared open pond at $16 \mathrm{~m}^{2}$ and water hyacinth was started severely attacked on November 2016, its disease incidence was $55 \%$ at $23^{\circ} \mathrm{C}$ and humidity $39 \%$, in December 2016 its disease incidence was $58.4 \%$ at humidity $31 \%$ and $23^{\circ} \mathrm{C}$, in January 2017 disease incidence was $65 \%$ at $26^{\circ} \mathrm{C}$ and humidity $25 \%$ and in Feb 2017 not record disease incidence because all leaves are attacked and dry and Disease severity was $100 \%$. However, in April 2017 due to the climate conditions becomes cold and rain the dried water hyacinth started make new shoot and at this time the disease severity was $90 \%$. Some species of Fungi found in Faba bean leaf and root can eradicate the healthy water hyacinth at above $26^{\circ} \mathrm{C}$ and at less than $25 \%$ Humidity.

Keywords: Fungus; Disease incidence; Disease severity; Humidity; Pathogen; Tissue death

\section{Introduction}

Water hyacinth is a free-floating perennial (or hydrophyte) plant native to tropical and sub-tropical South America. It has broad, thick, glossy, ovate leaves; it may rise above the surface of the water as much as 1 meter in height and have $80 \mathrm{~cm}$ root below the surface of water. The leaves are 10-20 cm across, and float above the water surface. They have long, spongy and bulbous stalks.

One of the fastest growing plants known, water hyacinth reproduces primarily by way of runners or stolons. Each plant additionally can produce thousands of seeds each year and seeds can remain viable for more than 28 years [1]. Some water hyacinths were found to grow up to 2 to 5 metres a day in some sites in Southeast Asia. It also doubles their population in two weeks. International Union for Conservation of Nature (IUCN's) lists this species as one of the 100 most dangerous invasive species and the top 10 worst weeds in the world.

The water hyacinth appeared in Ethiopia in 1965 at the Koka Reservoir and in the Awash River. Other infestations in the country include Gambela Region, the Blue Nile from just below Lake Tana into Sudan, and Lake Ellen near Alem Tena.

It affects navigation, water flow, recreational use of aquatic systems, and poses of mechanical damage to hydroelectric systems. It is also responsible for drastic changes in the plant and animal communities of fresh water environments and acts as an agent for the spread of serious diseases in tropical countries [2]. The impact of Eichhornia crassipes on the physicochemical characteristics of the water in general are declines in temperature, $\mathrm{pH}$, biological oxygen demand (organic load), and nutrient levels. Water hyacinth has spread throughout Africa causing widespread problems to millions of users of water bodies and water resources,

Biological control using plant pathogens has been shown to be highly effective against water hyacinth under experimental conditions. Several highly virulent fungal parasites are known to cause diseases of water hyacinth. Among the known pathogens are Acremonium zonatum, Alternaria alternate, Alternaria eichhorniae, Bipolaris spp., Fusarium chlamydosporum, 
Helminthosporium spp., Cercosporarodmanii, Myrothecium roridum, Rhizoctoniasolani and Uredo eichhorniae [3]. These fungi are easy and inexpensive to produce and therefore have potential for development as bio herbicides. Of these fungi Alternaria eichhorniae, Cercospora rodmanii and Fusarium chlamydosporum have been studied to a significant extent.

Therefore, because of environmental sustainability and cost effectively our researches were bio control agent to control water hyacinth at laboratory, green house and artificial pond level.

\section{Objective of the Study}

- Identify the major indigenous plant pathogenic associated with naturally fungus infected Faba bean

- $\quad$ Study the pathogenicity of fungi from infected Faba bean on water hyacinth.

- Develop appropriate protocol to isolate and to propagate fungus for eradicate water hyacinth application

\section{Material and Methods}

The study areas were located in northern part of Lake Tana specifically in Dembya woreda and Gondar zuria specifically Gorgora and Lemeba Arbatensa respectively. The study area is largely woina dega. (Mid altitude) and located between $12023^{\prime} 20^{\prime \prime} \mathrm{N} 12031^{\prime} 40^{\prime \prime} \mathrm{N}$ latitude and $37033^{\prime} 20^{\prime \prime} \mathrm{E}$ to $37038^{\prime} 00^{\prime \prime} \mathrm{E}$ longitude $[4,5]$.

The study design was laboratory based green house and pond experiment.

\section{Sampling method}

Surveying diseased Faba bean were conducted around Gondar to determine if any pathogens have potential as mycoherbicidal for water hyacinth and Faba bean leaves and roots were collected randomly from 3 werdas at 20 kebelase using plastic bags (Ambagyrorgise, Dabat and Debarke and Healthy water hyacinth was collected in Lake Tana and the fungus was isolated and screening using potato dectrose agar medium from infected leaf and root using accepted laboratory procedure [6].

\section{Whole plant pathogenicity test in temporary shade}

Healthy water hyacinth plants were collected from natural infestations and maintained in a sterilized condition. For the inoculation procedure, plants were kept in plastic pot filled with water and moisture containing sandy soil. In $250 \mathrm{ml}$ Erlenmeyer flask, each contains $100 \mathrm{ml}$ malt extract broth (MEB). The flasks were sterilized at $121^{\circ} \mathrm{C}$ for 20 minutes and inoculated after cooling with $2 \mathrm{~mm}$ plug of 7-10 day old cultures. The inoculums spore suspension was incubated at $25^{\circ} \mathrm{C}$ on rotary shaker for 5-7 days. The resulted 10 I mycelium suspension were diluted by 20 $\mathrm{ml}$ of peptone water for each replicate, for three replicate $30 \mathrm{ml}$ fungal suspension diluted with $60 \mathrm{ml}$ of peptone water. For comparison of pathogenicity, each suspension was then liberally applied to the surface of water hyacinth plants using a hand sprayer and all treated water hyacinth plant was covered by polythene tube sheet up to disease symptoms observed on leaf to minimize the disparity across each other treated plants and to was by water. Control plants were placed under the same conditions but without addition of the antagonists.

Data collection commenced immediately disease symptoms appeared and continued weekly up to a five week period. Plants with disease symptoms were recorded and scored to give disease incidence and severity [7]. The disease incidence (DI) was taken as the percentage number of leaves on the plant that exhibited disease symptoms. This was measured by observing all the leaves of the inoculated plant in each pot and calculated as percentage of the total number of leaves on the plant. Disease severity (DS) was determined for each leaf on a scale of 0 to 9, where $0=$ healthy, and $9=100 \%$ diseased (Freeman and Charudattan, 1984). Values for individual leaves were summed and averaged to derive DS for a whole plant. Finally, isolates were categorized into five groups: " $\mathrm{N}$ " isolates that did not cause any significant damage or infection, "Mild" isolates that caused less than $25 \%$ damage of the leaf area; "Low Moderate" isolates caused $26-50 \%$ damage of the leaf area; "High Moderate" isolates that damaged $51-75 \%$ of the leaf area and "Severe" fungi that cause greater than $75 \%$ damage of the leaf area.

\section{Data source and data collection methods}

Data were collected directly from detached leaf test and from the pot experiment plant by observation and using standard procedures.

\section{Data analysis}

Data was entered to computer by hand, and analysis was carried out using Statistical Package for Social Science (SPSS) version 16.0. Descriptive Statistics were employed to present the percentage of isolates. All the presently performed analyses were carried out in duplicate and the correlation were calculated [8]. Mean separation were carried out using the least significant differences (LSD) between means for the different treatments. $\mathrm{P}=0.05$ was taken as statistically significant association.

\section{Whole plant pathogenicity test in pond}

To show the effectiveness of those are effective fungus on temporary shade, it also tray in 16 sq metres artificial ponds by bringing the healthy water hyacinth and cultivating on it. The fungus showed high pathogen city in green house experiment were Rhizoctonia solani spp. Aspergillus flavus, Tricothcium roseum and Aspergillus niger and grown in $250 \mathrm{ml}$ flask each contain $100 \mathrm{ml}$ of PDA broth. By using pressure sprayer the fungus is released on prepared ponds in the areas of 16 metres square. Up to show symptoms of the yellow or necrotic leaf it was covered by clean plastic sheet.

\section{Data source and data collection methods}

The data were collected by divided four quadrant and regularly count the infected leaf in each month (September 
2016-April 2017) and data was entered to computer and analysis was carried out using excel sheet (Table 1).

Table 1: Modified naseema et al. (2001) disease.

\begin{tabular}{|c|c|c|c|c|c|}
\hline RS & Type of symptom produced/symptom description & Nov & Dec & Jan & Feb \\
\hline 1 & No symptom & & & & \\
\hline 2 & $1-9 \%$ symptom developed around the pin pricked area only & & & & \\
\hline 3 & $10 \%$ of the leaf area showing yellowing or browning & & & & \\
\hline 4 & $11-25 \%$ of the leaf area showing yellowing or browning & & & & \\
\hline 5 & $26-50 \%$ of the leaf area including petiole showing symptom & $-41.60 \%$ & & & \\
\hline 6 & $51-100 \%$ of the leaf area including petiole showing symptom to complete drying of the plant & & -52.4 & -76.5 & $100 \%$ \\
\hline
\end{tabular}

\section{Results and Discussion}

Out of 230 isolates fungi from different werdas, seven fungi species were affected the healthy water hyacinth leaf in green house experiment. Those fungi were, Tricothecium roseum, Aspergillus flaves, Trichoderma spp1, Fusarium spp, Rhizocotonia spp, Aspergillus niger and Trichdoerma spp (Table 2).

Table 2: Level of Disease intensity effects of fungal isolates on water hyacinth under pot experiment conditions.

\begin{tabular}{|c|c|c|c|c|c|c|c|c|c|c|}
\hline \multirow{2}{*}{ Species } & \multirow{2}{*}{ Week } & \multicolumn{3}{|c|}{ Total no of leaves } & \multicolumn{3}{|c|}{ Number of DI leaves } & \multicolumn{3}{|c|}{ Number of DS leaves } \\
\hline & & Pot 1 & Pot 2 & Pot 3 & Pot 1 & Pot 2 & Pot 3 & Pot 1 & Pot 2 & Pot 3 \\
\hline \multirow{4}{*}{$\begin{array}{l}\text { Tricothecium } \\
\text { roseum }\end{array}$} & 1 & 20 & 22 & 12 & 7 & 7 & 3 & 2 & 2 & - \\
\hline & 2 & 22 & 22 & 15 & 12 & 8 & 3 & 5 & 3 & 1 \\
\hline & 3 & 29 & 25 & 20 & 18 & 15 & 4 & 9 & 13 & 2 \\
\hline & 4 & 30 & 33 & 18 & 19 & 16 & 4 & 9 & 13 & 2 \\
\hline \multirow{4}{*}{ Aspergillu flaves } & 1 & 15 & 26 & 13 & 8 & 13 & 7 & 3 & 5 & 2 \\
\hline & 2 & 17 & 28 & 15 & 10 & 14 & 10 & 5 & 7 & 2 \\
\hline & 3 & 24 & 39 & 22 & 11 & 19 & 10 & 5 & 11 & 5 \\
\hline & 4 & 24 & 41 & 25 & 9 & 19 & 12 & 5 & 11 & 5 \\
\hline \multirow{4}{*}{ Trichoderma spp1 } & 1 & 17 & 13 & 19 & 4 & 3 & 3 & 1 & 1 & - \\
\hline & 2 & 20 & 16 & 21 & 6 & 6 & 4 & 2 & 1 & 1 \\
\hline & 3 & 25 & 20 & 25 & 7 & 8 & 10 & 4 & 6 & 3 \\
\hline & 4 & 25 & 20 & 31 & 10 & 7 & 11 & 5 & 6 & 4 \\
\hline \multirow{4}{*}{ Fusarium spp } & 1 & 20 & 19 & 20 & 6 & 7 & 8 & 2 & 1 & 4 \\
\hline & 2 & 23 & 25 & 21 & 8 & 9 & 8 & 2 & 4 & 5 \\
\hline & 3 & 30 & 40 & 25 & 10 & 24 & 13 & 3 & 21 & 6 \\
\hline & 4 & 30 & 45 & 28 & 14 & 28 & 14 & 8 & 22 & 7 \\
\hline \multirow{4}{*}{ Rhizoctonia spp } & 1 & 22 & 30 & 27 & 4 & 7 & 5 & 2 & 3 & 1 \\
\hline & 2 & 23 & 34 & 30 & 20 & 30 & 15 & 10 & 12 & 9 \\
\hline & 3 & 32 & 40 & 40 & 30 & 30 & 26 & 23 & 16 & 21 \\
\hline & 4 & 42 & 46 & 43 & 32 & 35 & 36 & 28 & 20 & 23 \\
\hline \multirow{2}{*}{ Aspergillus niger } & 1 & 24 & 13 & 15 & 9 & 2 & 5 & 3 & - & 1 \\
\hline & 2 & 27 & 16 & 17 & 19 & 5 & 6 & 10 & 2 & 2 \\
\hline
\end{tabular}




\begin{tabular}{|c|c|c|c|c|c|c|c|c|c|c|}
\hline & 3 & 35 & 17 & 22 & 19 & 7 & 6 & 12 & 2 & 4 \\
\hline & 4 & 37 & 19 & 23 & 20 & 9 & 6 & 15 & 3 & 4 \\
\hline \multirow{4}{*}{ Trihcoderma spp1 } & 1 & 15 & 12 & 19 & 2 & 2 & 2 & - & - & - \\
\hline & 2 & 16 & 13 & 20 & 5 & 7 & 6 & 1 & 2 & 3 \\
\hline & 3 & 15 & 19 & 27 & 7 & 8 & 11 & 4 & 4 & 4 \\
\hline & 4 & 22 & 18 & 25 & 7 & 9 & 11 & 4 & 5 & 4 \\
\hline \multirow{4}{*}{ Control } & 1 & 12 & & & & & - & - & - & - \\
\hline & 2 & 16 & & & & & - & - & - & - \\
\hline & 3 & 22 & & & & & - & - & - & - \\
\hline & 4 & 25 & & & & & - & - & - & - \\
\hline
\end{tabular}

$\mathrm{DI}=$ disease incidence, $\mathrm{DS}=$ disease severity

\section{Disease incidence}

At the end of the five weeks the highest disease incidence per plant was recorded in plants inoculated with Rhizoctonia spp (66.0\%) (Table 2). This was significantly higher than that of the Tricothecum roseium $(50.7 \%)(p=0.05)$ which was rated second followed by Aspergillus flaves (9.1\%) Fusarium spp (45.3\%) and Aspergillus niger (42.6\%). The least disease incidence was recorded in Trichoderma spp1 (34.2\%) and Trichoderma spp2 (31.3\%) significantly lower than the others. Disease symptoms cannot be observed on the control group.

\section{Disease severity}

On the basis of disease severity (DS) the pathogenic species were divided into less than $25 \%$ mild, low moderate isolates caused $26-50 \%$ damaged of the leaf area, high moderate isolates that damaged $51-75 \%$ of the leaf area and severely fungi that cause greater than $75 \%$ damage of the leaf area. Of these species only Rhizoctonia spp (100\%) and Fusarium spp (78.6\%) showed high disease severity [9]. These fungi were associated with a high percentage of tissue death after five weeks application. Aspergillus flaves, Tricothcium roseum and Aspergillus niger show high moderate disease severity $(58.3 \%$, $56.4 \%$ and $53.6 \%$ ) tissue death, respectively. Trichoderma spp2 (31.4.7\%) and Trichoderma spp1 (27.7\%) shows low moderate. Most isolates showed minimum lesion growth during the first week. Control plants not show disease severity (Figure 1).

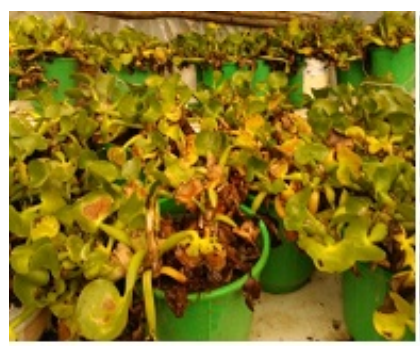

Treated by fungus

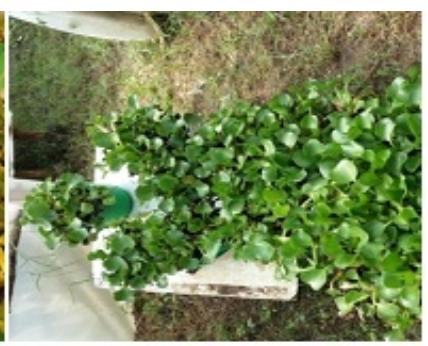

Control
Figure 1: Water hyacinth in temporary green house trial.
Also, the fugues those show promising result in temporary shade it have tried in the ponds in September 2016 and the released fungus to prepared pond started attacked the water hyacinth when the season becomes hot and during rain and cold condition they become latent or they do not show colour change or become necrotic on leaf at that time the area (our experiment place, Gondar) average temperature was $21^{\circ} \mathrm{C}$ and humidity 79\%, in September 2016, however the promising fungus that was effective on greenhouse highly attacked the water hyacinth on the ponds in October 2016-January 2017 in this time also the areas average Temperature $23^{\circ} \mathrm{C}$ and Humidity 39\% (Figures 2-5).

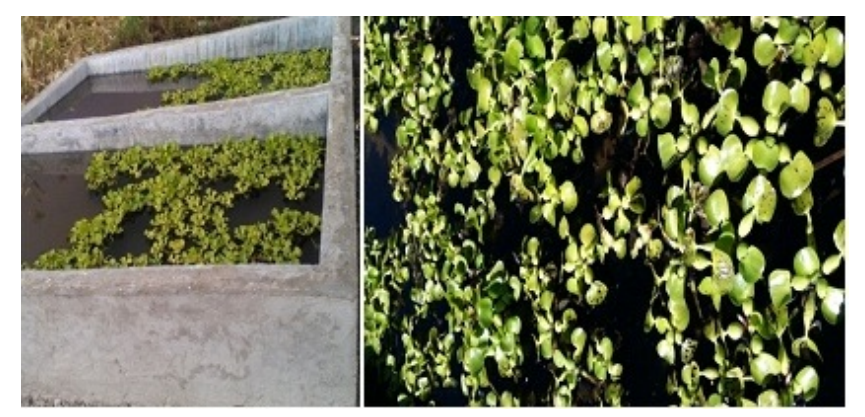

Figure 2. Before and after released fungi in October.
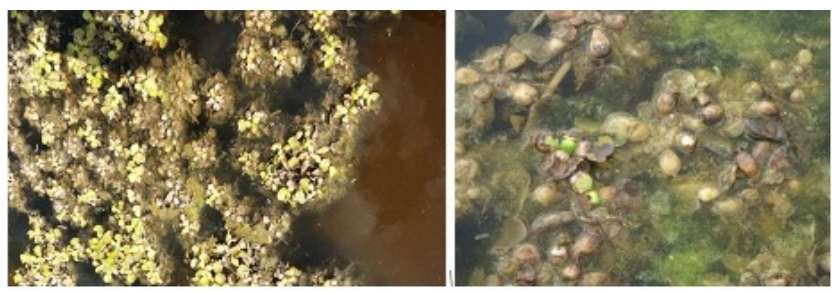

Figure 3: Water hyacinth in the pond in December 2017 after fungus released. 


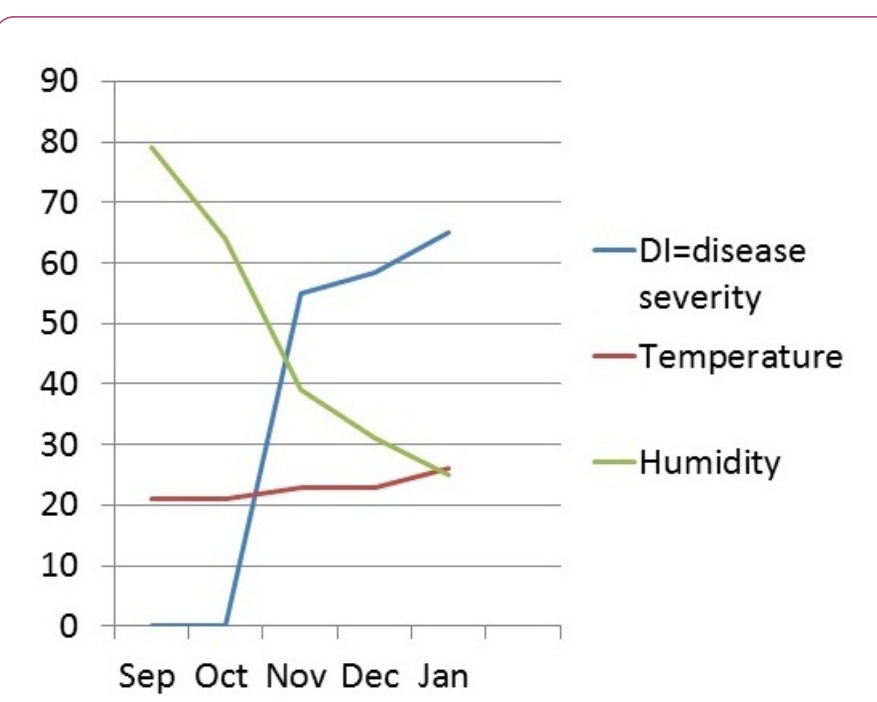

Figure 4: The fungus, Humidity and Disease severity association on water hyacinth leaf.

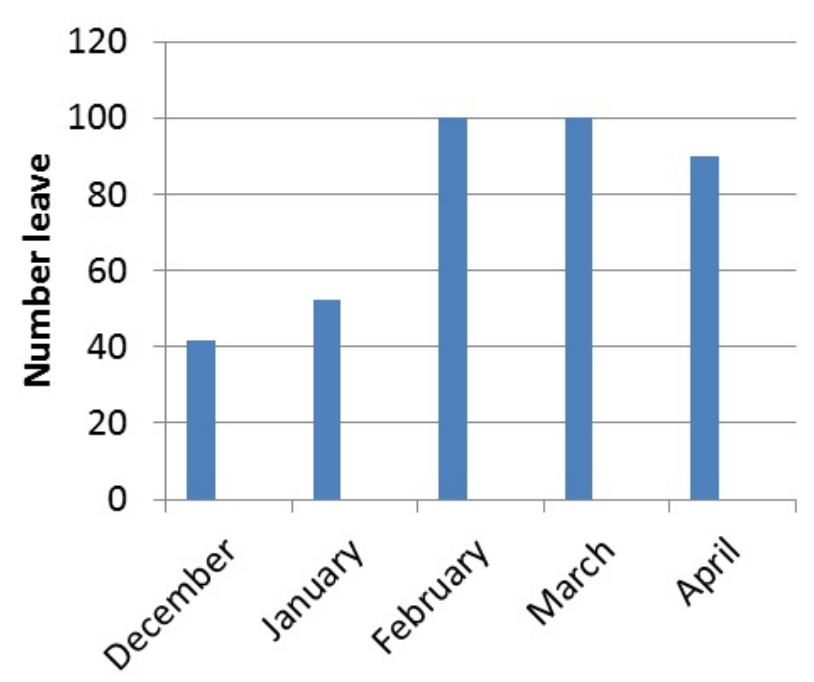

Figure 5: The fungus effect on water hyacinth leaf from Dec/ 2016-Apr/2017.

Similarly, pathogen city tests of indigenous fungal pathogens on water hyacinth were tried in different countries. For instance, surveys of fungal pathogens from water hyacinth infested water bodies like Lake Victoria, Lake Naivasha and Nairobi Dam in Kenya came up with 20 strains of pathogenic fungi. Pathogenicity tests were also carried out and Cercospora, Fusarium and Alternaria spp. were diagnosed as potential mycoherbicides. A pathogenicity study on $F$. equiseti by Firehun et al. (2006) showed up to $98.3 \%$ infection. Naseema et al. (2001) reported $62.7 \%$ infection due to this pathogen. Martinez and Charudattan (1998) reported that Alternarias spp. and
Fusarium spp. were highly virulent and severely damaged the inoculated water hyacinth leaves. Accordingly our research finding also related with this author because in our case Fusariume spp. was one of the promising biological control during temporary shade and pond trial.

\section{Conclusion}

Tricothecium roseum, Aspergillus flaves, Trichoderma spp1, Fusarium spp, Rhizocotonia spp, Aspergillus niger and Trichdoerma spp fungi were promising to eradicate water hyacinth at above $26^{\circ} \mathrm{C}$ and at less than $25 \%$ humidity. However, before tried to release to the lake the impacts of those species on biodiversity of the lake should be study by taking the representative aquatic biodiversity of the lake.

\section{Aknlowegment}

I would like to thank Ethiopian Environment and forest research institute and University of Gondar for financial support for this project.

\section{Reference}

1. Julien MH (2012) Eichhornia crassipes(Martius) SolmsLaubach - water hyacinth. In: Biological control of weeds in Australia. Julien $M$ (editors), et al. pp. 227-237. (CSIRO Publishing, Melbourne)

2. Duke J (1987) Eichhorniacrassipes, Handbook of Energy Crops. NewCROPS.

3. No authors (2014) California State Parks: Division of Boating and Waterways. State of California: Division of Boating and Waterways.

4. Maricela J (2014) Progress on water hyacinth (Eichhorniacrassipes) management. Food and Agriculture Organization of the United Nations.

5. Anushree M (2007) Environmental challenge vis a vis opportunity: The case of water hyacinth. Environ Int 33: 122-138.

6. Fessehaie R (2005) Water Hyacinth (Eichhorniacrassipes): A Review of its Weed Status in Ethiopia. Arem 6: 105-111.

7. Dearl S, Seth J, Bill K (2014) Invasive Aquatic Weeds in Louisiana. LSU AgCenter. Louisiana Agriculture.

8. Paul RS, Rod W (2012) Water hyacinth, Eichhorniacrassipes (Mart.) Solms, seed longevity and the implications for management. 18th Australasian Weeds Conference. Melbourne: Conference Proceedings CD.

9. Yao S (2010) Scientists Release Biocontrol for Waterhyacinth. United States Department of Agriculture, Agricultural Research Service. 